\title{
Prophylactic folic acid in women with pernicious anaemia pregnant after periods of infertility
}

\author{
MARION HALL AND RONALD J. L. DAVIDSON \\ From Aberdeen Maternity Hospital and the Laboratory, City Hospital, Aberdeen
}

SYNOPSIS The haematological and obstetric details of five women with Addisonian pernicious anaemia and infertility are described together with those of another patient who developed the anaemia soon after confinement. The implications are discussed, and it is concluded that the prophylactic administration of small doses of folic acid during pregnancy is a safe procedure while the risk of precipitating subacute combined degeneration of the cord in undiagnosed Addisonian pernicious anaemia is hypothetical. Although the mechanism of the infertility in pernicious anaemia remains undefined, several factors which may be of aetiological significance are considered.

The prevalence of folic acid deficiency during pregnancy is well recognized and the prophylactic administration of small doses of this vitamin routinely in pregnancy has been widely advocated (Dawson, More, and Aird, 1962; Chanarin, Rothman, and Berry, 1965; Giles, 1966). These workers have qualified their recommendation, however, by drawing attention to the remote danger of precipitating subacute combined degeneration of the cord in an undiagnosed case of Addisonian pernicious anaemia. Some (Camilleri, 1960; Varadi, 1964) have gone so far as to oppose its routine administration during pregnancy because of this risk. Like all previous authors we have been unable to trace in the literature a report of either a case of this unlikely complication or, probably of even greater significance, any case of Addisonian pernicious anaemia initially diagnosed during pregnancy.

Since large numbers of pregnant women all over the world have, in recent years, been given folic acid without any reported ill effects it would appear that the risk of precipitating subacute combined degeneration of the cord in unrecognized Addisonian anaemia during pregnancy is purely hypothetical.

The opinion, based on general experience, has been previously expressed that patients in the childbearing age group with Addisonian pernicious anaemia may be infertile (Lillie, 1962; Sharp and Witts, 1962). Our interest in this subject was stimulated by seeing a 33-year-old patient who conceived twins within a month of starting vitamin $B_{12}$ treatment for pernicious anaemia, and had previously

Received for publication 12 December 1967. been involuntarily infertile throughout her seven years of married life (patient 3, Tables I and II). In an attempt to assess the possible relationship between Addisonian pernicious anaemia and infertility, a search was made for similar cases occurring in the last five years in the records of Aberdeen Maternity Hospital. The purpose of this paper is to present the haematological and obstetric details of the six cases found and to discuss the implications of our findings.

\section{HAEMATOLOGICAL AND OBSTETRIC DETAILS}

The haematological details of patients 1 to 5 are shown in Table I. The peripheral blood and marrow changes were diagnostic of megaloblastic haemopoiesis. All had histamine-fast achlorhydria, and although serum $B_{12}$ assays and radioactive $B_{12}$ absorption studies were not carried out in patients 1 and 2, both fulfilled the haematological and clinical criteria for the diagnosis, including the therapeutic response to vitamin $B_{12}$.

The ages and obstetric details of the same five patients are shown in Table II. No patient had amenorrhoea, which may occur in Addisonian pernicious anaemia (Britton, 1965) nor any menstrual irregularity. Before the diagnosis, all had relative infertility of several years' duration and in patients 3,4 , and 5 this had been involuntary. Patient 5 had previously undergone investigation for infertility as she had only two live children.

As shown in Table II, all five patients became pregnant following the diagnosis of Addisonian 
pernicious anaemia and its treatment with vitamin $B_{12}$, three of them within four months of starting treatment. The delay in conception in patients 1 and 2 was due to the use of contraceptives. Patient 1 had undergone two pelvic floor repairs and was advised to avoid further child bearing. Patient 2 did not want to have a family because she did not feel strong enough.

In contrast to the five patients just described, patient 6 developed Addisonian pernicious anaemia only six months after confinement. This patient, now aged 37 years, had previous normal pregnancies in 1954, 1958, and 1960 after which she practised contraception. Six years later she inadvertently became pregnant and gave birth to a full-term mongol infant in October 1966. She had no anaemia during this pregnancy or puerperium but in April 1967, she complained of tiredness and her family doctor referred her for haematological investigation which showed a haemoglobin level of $59 \%(6.8 \mathrm{~g})$ and a macrocytic blood picture. Subsequently sternal marrow puncture showed florid megaloblastic haemopoiesis; an augmented histamine test achlorhydria; serum $B_{12} 62 \mu \mu \mathrm{g} / \mathrm{ml}$; serum folate $3 \mathrm{~m} \mu \mathrm{g} / \mathrm{ml}$; antigastric antibodies, strongly positive. A full clinical and haematological remission followed treatment with vitamin $B_{12}$.

\section{DISCUSSION}

Severe anaemia, irrespective of aetiology, may in a variety of ways reduce fertility, and, as all our patients had a severe degree of anaemia, this must be considered as possibly having contributed towards their infertility. We regard this factor, however, to be of little significance for the following reasons. First, it is reasonable to assume that the marked degree of anaemia found at the time of diagnosis of Addisoniam pernicious anaemia did not extend throughout tho period of infertility and, secondly, in one patien conception actually occurred while the anaemia was still responding to vitamin $B_{12}$ treatment.

As it is known that the incidence of pernicious anaemia increases and fertility declines with ageas Dawson et al (1962) suggested that age might be the main cause of infertility in these circumstances Apart from the fact that two of the patients in our series were under 30 years of age, the observation that pregnancy occurred within months of starting vitamin $B_{12}$ treatment in the remaining three patients. and in the five similar cases described by Adam? (1958) would appear to indicate that age was not $\vec{a}$ contributory factor. On the other hand, it seems reasonable to attribute their infertility to the vitamin $B_{12}$ deficiency state itself. Although the mechanisin of this relationship must remain largely speculative the conclusion appears valid and gains suppore. from the fact that infertility may also be encountere $\$$ in males with Addisonian pernicious anaemi (Watson, 1962; Furnass, 1963).

The following factors acting alone or in combinas tion during the earlier phases of the reproductive process in female patients may account for the infertility.

OVULATION Amenorrhoea may be a feature i⿺ some women with pernicious anaemia, and even in those apparently menstruating normally the cycles may be anovulatory. Hence it may be questioneक whether ovulation occurs at all in establisheep Addisonian pernicious anaemia.

ABNORMALITIES OF THE OVUM If ovulation doe occur, developmental abnormalities or chromosoma 
anomalies of the ovum may prevent its fertilization or subsequent implantation, growth, and maturation. It seems reasonable to assume, especially if one views Addisonian pernicious anaemia as a widespread nutritional cytological dystrophy (Mallarmé, 1948), that the ovum, like the developing erythroblast, may fail to synthesize sufficient DNA for normal cell division in the absence of normal supplies of vitamin $B_{12}$ or folic acid. This 'maturation arrest' may thus result in death of the ovum before or shortly after fertilization. Similarly it may be argued that chromosomal anomalies may arise in the ovum, as in the case of the megaloblast where they are frequently seen, usually as Howell-Jolly bodies representing chromosomal dislocations (Hutchison and FergusonSmith, 1959). This assumption is supported by the suggestion that folic acid deficiency may have a teratogenic effect (Maughan, 1962; Pritchard, 1962) and that the use of the folic acid antagonist aminopterin as an abortifacient may produce monstrosities when it fails to induce abortion (Goetsch, 1962).

It is of interest to speculate that a very early vitamin $B_{12}$ deficiency in patient 6 of this series may have accounted for the trisomy of the baby. Unfortunately neither vitamin $B_{12}$ nor folic acid assays were carried out during the pregnancy because the patient had no anaemia.

ABNORMALITY OF ENDOMETRIUM AND PLACENTA Apart from developmental and chromosomal abnormalities in the fertilized ovum itself, implantation and growth of the blastocyst may be impaired or prevented by a cytologically or functionally defective endometrium. Although no study of the endometrium in Addisonian pernicious anaemia appears to have been made, nuclear and cytoplasmic changes have been observed in cells from many different epithelial surfaces including those from vagina and cervix (Lancet, 1960). Epithelial surfaces exhibiting these changes usually show a varying degree of atrophy, eg, the tongue, and hence a reduction in functional capacity. In the case of the endometrium, a tissue of high cytological and mitotic activity, it seems logical to conclude that any arrest of cell maturation or division may lead to complete or partial failure in its proliferative or secretory stages of development. An additional factor in endometrial dysfunction in vitamin $B_{12}$ or folic acid deficiency may be an impairment in response to hormonal stimulation; as in the rat, it is known that oestrogens act at the cellular level by promoting synthesis of nucleic acid and proteins in oestrogen-dependent tissues (Mueller, Herranen, and Jervell, 1958). The levels of hormone to which the endometrium is exposed may also be altered. For example, defective cell development of the corpus luteum may lead to a reduction in the quantity of progesterone produced by this organ. Any or all of these factors may lead to infertility or repeated early abortion. The latter may be indistinguishable clinically from cyclical menstruation and thus may present as 'infertility'.

We would assert that patients with well developed Addisonian pernicious anaemia are usually if not always infertile and that this would explain why there is no report of subacute combined degeneration of the cord having been precipitated in undiagnosed Addisonian anaemia during pregnancy by the administration of folic acid supplements. It would, therefore, seem justifiable to regard the risk as being purely hypothetical.

Further, this unproven risk is made even more tenuous if folic acid is prescribed in small doses $(300 \mu \mathrm{g} /$ day $)$, as recently recommended by Willoughby (1967), because there is evidence to suggest that in non-pregnant patients with Addisonian anaemia, folic acid in doses of less than $5 \mathrm{mg} /$ day rarely causes neurological relapse and that even with doses of as much as $15 \mathrm{mg} /$ day, subacute combined degeneration of the cord usually develops only after nine to 12 months (Ross, Belding, and Paegel, 1948).

In our opinion a far more important and realistic danger, upon which very little stress has so far been laid, is that of patients continuing to take folic acid tablets left over from their pregnancy. This danger might be greatest where combined iron/folic acid preparations are used or where folic acid has been prescribed for puerperal megaloblastic anaemia. We feel that unless a limited quantity of folic acid is prescribed during the pregnancy or unless patients are specifically instructed to cease taking folic acid after confinement, women, such as patient 6 in this series, who developed overt Addisonian anaemia within six months of delivery, may be exposed to an unnecessary and preventable hazard.

Although the advantages of the routine administration of small doses of folic acid during pregnancy are well established and widely recognized, it is hoped that our findings will alleviate if not finally eliminate the fears of the few who still express reservations regarding the safety of the procedure.

Finally, although Addisonian pernicious anaemia is not common in the childbearing age group, our findings do not concur with the recently expressed view that this type of anaemia 'is excessively rare under the age of 40' (Richmond, 1967). We would strongly recommend that $(a)$ serum $\mathrm{B}_{12}$ and folate assays be included as routine procedures in the investigation of all infertile female patients, and (b) any woman who is found to have Addisonian pernicious anaemia in the reproductive period of life be warned of the possible enhancement of fertility 
following treatment, a step which may avoid the arrival of a late and in some instances unwanted child.

We wish to thank Professor Ian MacGillivray and Dr William Walker for their helpful criticism and for reviewing the manuscript.

\section{REFERENCES}

Adams, J. F. (1958). Scot. med. J., 3, 21.

Britton, C. J. C. (1963). Whitby and Britton's Disorders of the Blood, 9th ed., p. 249. Churchill, London.

Camilleri, A. P. (1960). Brit. med. J., 2, 859.

Chanarin, I., Rothman, D., and Berry, V. (1965). Ibid., 1, 480.

Dawson, D. W., More, J. R. S., and Aird, D. C. (1962). Lancet, 2, 1015.

Furnass, S. B. (1963). Ibid., 1, 59.

Giles, C. (1966). J. clin. Path., 19, 1.

Goetsch, C. (1962). Amer. J. Obstet. Gynec., 83, 1474.

Hutchison, H. E., and Ferguson-Smith, M. A. (1959). J. clin. Path. 12,451 .
Lancet (1960). 2, 591.

Lillie, E. W. (1962). J. Obstet. Gynaec. Brit. Cwlth., 69, 736.

Mallarmé, J. (1948). Blood, 3, 103.

Maughan, G. B. (1962). Amer. J. Obstet. Gynec., 83, 1018.

Mueller, G. C., Herranen, A. M., and Jervell, K. F. (1958). Recent Progr. Hormone Res., 14, 95.

Pritchard, J. A. (1962). Amer. J. Obstet. Gynec., 83, 1004.

Richmond, J. (1967). Prescrib. J., 7, 43.

Ross, J. F., Belding, M., and Paegel, B. L. (1948). Blood, 3, 68.

Sharp, A. A., and Witts, L. J. (1962). Lancet, 2, 779.

Varadi, S. (1964). Ibid., 1, 1331.

Watson, A. A. (1962). Ibid., 2, 664

Willoughby, M. L. N. (1967). Brit. J. Haemat., 13, 503.

\section{ADDENDUM}

Since this paper was written, Jackson, Doig, and McDonald (Lancet, 1967, 2, 1159) have described a further eight women with pernicious anaemia ando infertility, seven of whom became pregnant within a year of starting treatment with vitamin $B_{12}$. 